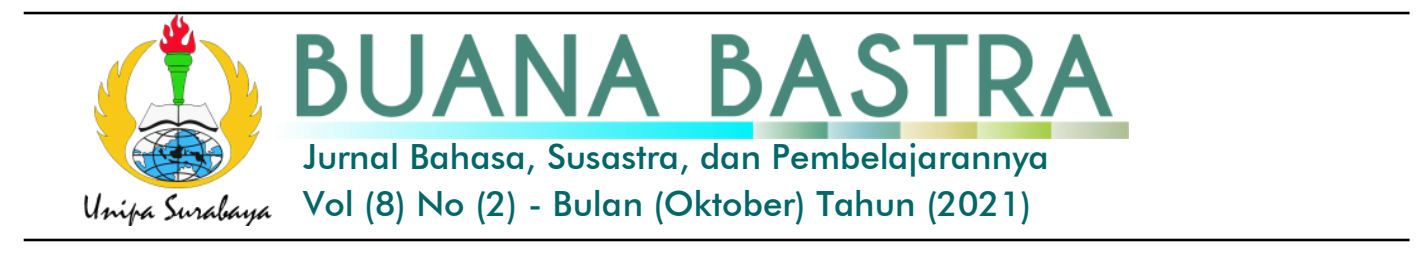

\title{
HEGEMONI DALAM NOVEL "ENTROK" KARYA OKKY MADASARI
}

\author{
Eko Cahyo Prawoto \\ Program Studi Pendidikan Bahasa Indonesia, Fakultas Ilmu Sosial dan Humaniora, \\ Universitas PGRI Adi Buana \\ eko.cahyo@unipasby.ac.id
}

\begin{abstract}
ABSTRAK: Dalam upaya mengetahui praktik-praktik hegemoni yang terjadi dalam novel Entrok perlu dilakukan pengkajian lebih dalam melalui teori hegemoni. Secara garis besar hegemoni merupakan teori yang berisi tentang bentuk propaganda dan wacana persuasif yang dilakukan oleh penguasa kepada masyarakat. Praktik hegemoni tidak saja dapat dilakukan secara kelompok, namun juga dapat dilakukan melalui instansi-instasi atau lembaga-lembaga pemerintahan. Penelitian ini menggunakan pendekatan kualitatif deskriptif. Adapun data pada penelitian ini ialah kalimat dan paragraf yang mengarah pada praktik hegemoni yang dilakukan negara kepada masyarakatnya pada novel "Entrok" karya Okyy Madasari. Berdasarkan hasil penelitian yang dilakukan, ditemukan beberapa bentuk hegemoni yang dilakukan oleh negara kepada masyarakat. Adapun bentuk hegemoni ideologi terwujud dalam bentuk: pertama, kekerasan secara verbal yang dilakukan oleh aparatur negara (Tentara/Polisi), kedua, kekerasan yang dilakuan dengan fisik dilakukan oleh aparut negara (Tentara/Polisi). Penerapan Hegemoni seperti pada bagian sebelumnya, merupakan wujud dari keseriusan negara dalam menjaga stabilitas kekuasaan, tanpa memedulikan hak masyarakat.
\end{abstract}

Kata kunci: Entrok, Hegemoni, Propaganda

ABSTRACT: In an effort to find out the hegemonic practices that occur in the novel Entrok, it is necessary to conduct a deeper study through the theory of hegemony. Broadly speaking, hegemony is a theory that describes the forms of propaganda and persuasive discourse carried out by the authorities to the public. The practice of hegemony can not only be done in groups, but can also be done through government agencies or institutions. The study used a descriptive qualitative approach. The data in this study are sentences and paragraphs that lead to the practice of hegemony carried out by the state to its people in the novel "Entrok" by Okyy Madasari. Based on the results of the research conducted, it was found that several forms of hegemony were carried out by the state to the community. The forms of ideological hegemony are manifested in the following forms: first, verbal violence perpetrated by state apparatus (Army/Police), second, physical violence perpetrated by state apparatus (Army/Police). The implementation of hegemony, as in the previous section, is a manifestation of the seriousness of the state in maintaining the stability of power, regardless of the rights of the people. 
Keywords: Entrok, Hegemony, Propaganda

\section{PENDAHULUAN}

Indonesia sebagai negara yang menganut paham demokrasi, memiliki permasalahan sosial yang sangat kompleks. Hal tersebut terjadi, sebab Indonesia memiliki keragaman dalam berbagai aspek. Mulai dari suku, agama, budaya, seni, tradisi, serta kondisi geografis yang melahirkan gab dan kesenjangan. Kesenjangan-kesenjangan yang muncul menimbulkan adanya friksi yang bersifat horizontal dan vertikal.

Negara sebagai organisasi terbesar memiliki peran penting dalam menjaga keharmonisan masyarakatnya, tanpa memedulikan latar belakang apapun. Namun demikian dalam perjalananya, Indonesia yang dikenal dengan negara paham demokrasi masih perlu banyak belajar, terutama dalam mengatasi permasalahanpermasalahan sosial.

Dalam satu abad terakhir salah satu kajian sosiologi yang hangat diperbincangkan ialah hegemoni. Hegemoni merupakan sebuah teori yang mengandung paham yang berorientasi pada "kesepakatan" antara kelas dominan serta kelas yang terdominasi. Konsep hegemoni yang dikemukakan Gramsci dapat dilakukan dengan dua hal, yakni; kekerasan secara fisik serta propaganda yang bersifat persuasif.

Dalam praktik hegemoni, kelas-kelas masyarakat yang memiliki kedudukan lebih tinggi mendominsai kelas-kelas yang lebih rendah, kelas dominan dapat terepresentasikan dalam dua kelompok. Pertama kelompok yang memiliki otoritas seperti Pemerintah, Polisi, TNI. Kedua lembaga pranata-pranata yang terdapat di masyarakat misalnya pendidikan, pondok pesantren, LSM dll. (Simon,1999:19)

Konsep hegemoni yang dikemukakan Gramsci tidak terlepas dari paham Marxis, sebab Gramsci juga merupakan penganut Marxis, tetapi konsep Marxis bagi Gramsci tidak lebih dari sebuah inspirasi, ketika melihat permasalahan korporasi yang terjadi di negaranya. Melalui hegemoni Gramsci meletakkan posisi antara proletar dan borjuis tidak seperti dalam paham Marx. Sebab hegemoni membahas persuasi serta kekerasan yang dilakukan dalam upaya mencapai konsensus.

Praktik hegemoni tidak hanya bisa ditemui dalam kehidupan nyata, namun juga tereprentasikan dalam karya sastra. Kisah-kisah yang tertuang dalam Pabrik karya Putu Wijaya, Lampuki karya Arafat Nur, Delapan Enam serta Entrok karya Okky Madasari, kental dengan praktik hegemoni yang dilakukan oleh negara.

Entrok ialah novel yang mengisahkan kehidupan antara ibu dan anak perempuan, kedua tokoh tersebut menjadi pemeran utama dalam perjalanan hidup yang penuh dengan pilu dan kegamangan, ia "kegamanan" ialah kata yang tepat untuk mewakili rasa yang ingin diimajikan penulis melalui kisah pasang surut kehidupan. 
Ibu yang menjadi salah satu tokoh utama dalam novel tersebut bernama Marni. Marni adalah perempuan desa yang ulet dan pekerja keras, karakter tersebut ditunjukkan melalui rangkaian kisah pilu mulai dari kecil hingga ia menjadi wanita yang sukses. Singkat cerita pada mulanya Marni adalah seorang gadis kecil yang sering kali diajak bunya ke pasar, untuk menjadi seorang kuli panggul. Setelah ia merasa memiliki modal ia kemudian berpikir untuk memulai usaha. Dari sinilah kisah sukses Marni di mulai.

Bermodalkan sedikit tabungan Marni, memberanikan diri untuk mencoba peruntungan dengan berjualan kebutuhan pokok sehari-hari di kampungnya, letak kampung yang cukup jauh dari pasar membuat orang-orang di sekitar rumah Marni kemudian memilih untuk berbelanja ke Marni. Setiap hari ia harus ke pasar untuk membeli kebutuhan seperti sayur, lauk, pauk, dan bumbu dapur. Usaha yang dirintis tersebut terus berkembang. Dari keuntungan dagang tersebut, Marni membeli sawah, membeli pick up, dan membangun rumah, dengan modal yang semakin banyak. Marni juga mengembangkan usahnya menjadi seorang rentenir. Bermula dari sinilah cobaan demi cobaan hinggap dalam kehidupan Marni.

Untuk mendapatkan keamanan dalam menjalankan usahanya, Marni kemudian harus membayar uang keamanan setiap bulan kepada apparat. Setiap kali apparat datang Marni selalu merasa gusar, tidak tenang, sebab selalu ada saja permintaan yang aneh-anhe dan tidak masuk akal dari aparat yang meminta uang jatah bulanan.

Komandan Sumardi masih tertawa. Entah apa yang lucu dari kata-kata Ibu.

Lalu ia berkata, "Beres. Silakan sampeyan terus cari rezeki. Tapi mulai sekarang, setiap empat belas hari, sediakan jatah duit keamanan. Nanti akua atau anak buahku yang ambil ke sana (Madasari, 2010:77).

Praktik-praktik yang dilakukan aparat dalam novel tersebut menjadi bukti bahwa, hegemoni tidak saja merupakan realitas yang sengaja dikaburkan pada 1990-an. Hal itu, menjadi sangat kentara ketika pembaca memahami secara intuitif antara masyarakat, kekuasan serta politik pada masa itu.

Gramsci (Simon, 1999:103) menyatakan, dalam praktik politik, masyarakat sipil dianggap sebagai etika dan moral yang menjadi modal di mana hegemoni menjadi dominan karena dibangun dengan mekanisme perjuangan ideoilogis dan politik. Dari pernyataan tersebut jelaslah bahwa negara sebagai pelaku hegemoni atas masyarakatnya.

Untuk mengetahui praktik-praktik hegemoni yang terjadi dalam novel Entrok perlu dilakukan pengkajian lebih dalam melalui teori hegemoni. Secara garis besar memaparkan tentang propaganda antara kelompok dominan terhadap kelompok yang terdominasi. Praktik hegemoni tidak saja dapat dilakukan secara kelompok, namun juga dapat dilakukan melalui instansi-instasi atau lembagalembaga resmi pemerintahan.

\section{A Hegemoni}

Pada awal abad ke-19 salah satu kajian dalam ilmu sosiologi yang cukup sering diperbincangkan dalam berbagai forum ilmiah di kalangan akademisi, 
politikus, serta sosialis ialah hegemoni. Hal terssebut tentunya tidak terlepas dari kondisi politik di beberapa negara pada waktu itu, misalnya revolusi yang terjadi Rusia, China, serta kondisi sosial yang terjadi Italia memberikan pengaruh besar terhadap lahirnya pemikiran hegemoni Antonio Gramsci.

Pada dasarnya, perbincangan hegemoni akan selalu dikaitkan dengan marxis. Sebab kelahiran ideologi hegemoni merupakan tidak terlepas dari paham marxis, yang menandai hubungan antara oposisi-biner, antara kelompok dominan dan kelompok yang terdominasi. Namun demikian, dalam hegemoni tidak hanya berbicara kapitalis. Permasalahan yang relevan dengan hegemoni lebih mengarah kepada permasalahan-permasalahan politik serta kekuasaan. Sebab, secara etimologi hegemoni secara etimologi berasal egemonia dalam bahasa Yunani yang berarti penguasa.

Perjalanan Gramsci ke Rusia membawa ia ke dalam pemikiran yang mengarah pada analisis terhadap hubungan antara penguasa dengan masyarakat. Dalam praktiknya prinsip hegemoni merupakan penguasaan terhadap kelompok sosial melalui kepemimpinan intelektual.

Menurut Gramsci (Faruk, 2012:141) prinsip metodologis digunakan dalam studi-studinya didasarkan pada dua hal, yakni; pertama, ialah pernyataan bahwa adanya kelompok sosial yang mendominasi kelompok lain, kedua ialah kepemimpinan moral dan intelektual yang digunakan untuk mendominasi, dan bahkan dengan kekuatan aparat dalam suatu negara.

Pemikiran Gramsci menunjukkan dua hal penting, dalam upaya menjalankan praktik hegemoni, yakni dominasi dan kepemimpinan. Dalam hal itu, yang perlu dipahami adalah cara-cara atau alat yang digunakan untuk memperoleh dominasi serta kepemimpinan. Secara praktis dalam hegemoni, kelompok dominan lebih cenderung menciptakan wacana atau cara berpikir tertentu yang menjadi konsumsi kelompok yang terdominasi, hal itu dilakukan untuk menenggelamkan pemikiran-pemikiran yang mengarah pada unsur pemaksaan.

Hal tersebut didukung pernyataan Faruk (2012:132), bahwa hegemoni terwujud dalam "kepemimpinan". Istilah tersebut seirng kali digunakan para komentator politik. Sehingga dapat dikatakan bahwa hegemoni mencakup sesuatu yang lebih kompleks, Gramsci memakai konsep tersebut untuk lebih mengenali dan mengkaji bentuk-bentuk kultul, politik, dan ideologi dalam suatu tatanan masyarakat, bahwa suatu kelas fundamental yang memiliki system kepemimpinan merupakan upaya yang digunakan untuk membangun dominasi yang berbeda yang tidak bersifat memaksa.

Praktik hegemoni tidak hanya terdapat dalam satu bentuk. Hal tersebut meperjelas bahwa pada dasarnya hegemoni menciptakan permasalahan yang lebih kompleks di mana propaganda yang bersifat persuasif menjadi sebuah wacana yang logis serta bisa diterima oleh masyarakat yang terdominasi. 
Hal tersebut sangat relevan dengan kondisi politik yang tergambar dalam novel Entrok. Meskipun tidak disajikan secara dominan, namun permasalahan politik Indonesia dapat dipahami melalui propaganda-propaganda aparat yang memiliki kekuasaan serta kekuatan dalam mengarahkan, melarang, serta memberikan pendidikan kepada masyarakat sesuai dengan keinginan penguasa pada tahun 1990-an.

Berdasarkan pendapat di depan dapat dipahami, bahwa praktik hegemoni ialah upaya yang dilakukan untuk menciptakan serta melindungi kekuasaan. Sebab melalui dominasi dan kepemimpinan kekuasaan tidak akan mendapatkan ancaman dari kelompok yang terdominasi. Selain itu, praktik hegemoni juga dilakukan melalui propaganda yang dilakukan oleh penguasa, maupun melalui aparatnya, secara terstruktur sehingga dapat mengakibatkan lahiranya pola pikir yang kerdil serta jauh dari sifat kritis.

\section{METODE}

Penelitian ini menggunakan metode penelitian kualitatif deskriptif. Metode kualitatif deskriptif dipilih sesuai dengan tujuan dan sifat penelitian yang dilakukan. Adapun data pada penelitian ini terwujud dalam kalimat, dialog, serta paragraf yang mengarah pada praktik hegemoni yang dilakukan oleh negara kapada masyarakatnya. Selanjutnya, sumber data yang digunakan pada penelitian ini ialah Novel "Entrok" karya Okky Madasari, yang terbit pada tahun 2010.

Teknik pengumpulan data dilakukan melalui beberapa tahapan, yakni; 1) membaca novel secara keseluruhan untuk mendapatkan pemahaman yang utuh, 2) dilakukan pengodean terhadap data yang mengarah pada praktik hegemoni, 3) dilakukan penulisan ulang data yang diperoleh pada tahap sebelumnya, 4) dilakukan pengklasifikasian data sesuai dengan bentuk-bentuk hegemoni yang tersaji, 5) dilakukan pengulangan pada setiap tahapan apabila dirasa perlu untuk mendapatkan data yang sesuai dengan tujuan, sampai dengan cukup.

Selanjutnya, terdapat beberapa tahapan dalam teknik penganalisisan, yakni; 1) berdasarkan data yang diperoleh pada tahap sebelumnya, diinterpretasi untuk memberikan penafsiran terhadap data yang diperoleh, sesuai dengan praktik hegemoni, 2) eksplanasi dilakukan untuk memberikan penjelasan secara lebih lanjut mengenai hasil interpretasi, 3) pendeskripsian atau penguraian setiap hasil interpretasi dan eksplanasi dengan sejelas-jelasnya sesuai dengan praktik hegemoni.

data Pada bagian penganalisisan data dilakukan dengan tahapan-tahapan berikut, yaitu; 1) data yang diperoleh didentifikasi, selanjutnya dianalisis sesuai dengan teori yang digunakan, 2) kemudian diinterpretasi pada setiap data, 3) eksplanasi dilakukan untuk menguraikan fakta-fakta yang diperoleh, 4) pendeskripsian melalui penejalasan berdasarkan data dan teori yang digunakan.

\section{PEMBAHASAN}


Pada pembahasan ini akan diuraikan praktik-praktik hegemoni yang dilakukan oleh negara dalam novel Entrok karya Okky Madasari. Pada novel tersebut praktik hegemoni yang dilakukan negara lebih mengarah pada praktik penanaman ideologi. Sebab banyak ditemukan fakta-fakta mengenai wacana yang dilakukan oleh negara, dengan tujuan memengaruhi, mengajak, meyakinkan serta menekan masyarakat untuk mau mengikuti segala sesuatu yang diperintahkan oleh negara. Berikut adalah wujud hegemoni pada novel Entrok karya Okky Madasari.

"Hasyah..sudah tidak usah ngeyel. Pokoknya sampeyan sudah jadi musuh banyak orang, yang artinya musuh negara juga."

"Musuh orang banyak siapa, Ndan? Wong mereka datang mau minta tolong."

Terserah Sampeyan mau ngomong apa. Yang penting nyatanya seperti itu. Sekarang terserah Sampeyan mau butuh aman tau tidak." (Madasari, 2010:70).

Hegemoni yang dilakukan negara seperti pada kutipan tersebut didasarkan pada propaganda untuk menumbuhkan rasa takut pada masyarakat, sehingga dengan demikian aparat dapat mendikte masyarakat untuk mau mengikuti perintah aparat yang menagatasnamakan negara. Negara memiliki kekuasaan tanpa batas untuk mendikte segala aktifitas masyarakatnya, dengan tujuan memperkuat kapitalisme kelompok maupun individu pada masa Orde Baru.

Heryanto Philpott, 2003:228) pandangan yang dominan dalam diskursus politik Indonesia adalah bahwa pertumbuhan otoritas negara (yang lebih besar jika dibandingkan dengan masa-masa akhir pemerintahan Soekarno) dan efisiensi mendorong pada 'implementasi' pembangunan yang berhasil. Meningkatnya otoritas negara ini secara luas dipahami terjadi dengan mengorbankan 'masyarakat sipil'.

Heryanto (Philpott, 2003:229) lebih lanjut menyatakan, tak ada keraguan bahwa pemerintah Orde Baru menggunakan kontrol atas masyarakatnya secara lebih ketat, lebih efektif dan lebih otoriter dari pada masa pemerintahan Soekarno. Orde Baru menggunakan teror, pembunuhan, intimidasi dan bentuk-bentuk intervensi lainya untuk membungkam penentangan masyarakat, mengontrol kelompok kepentingan tertentu seperti jurnalis, atau mengekang kegiatan-kegiatan gerakan oposisi yang berbasis massa luas.

Hegemoni yang terpresentasikan pada kutipan tersebut merupakan wujud dari penanaman ideologi, bahwa aparat negara sebagai alat pemerintah memiliki perngaruh kuat untuk memberikan propaganda kepada masyarakat. Propaganda memberikan disampaikan kepada masyarakat menyebabkan timbulnya ketidaknyamanan masyarakat, misalnya takut dan cemas dengan peristiwaperistiwa kekerasan, intimidasi serta diskriminasi.

Hari-hari terasa mudah dan begitu teratur bagi Ibu. Sejak dia mengikuti kemauan Komandan dan Pak lurah, taka da lagi orang-orang bersarung yang datang saat subuh dan menyebutnya renternir langsung di depan hidungnya. Orang-orang hanya berani berbicara di balik punggung, dan bermanis-manis ketika di depan muka (Madasari, 2010:81)

Data tersebut merupakan bukti bahwa negara memiliki fungsi dalam menciptakan keamanan bagi masyarakat, masyarakat sangat bergantung pada keamanan yang diselenggarakan oleh negara. Hanya saja ketergantungan itu, 
memiliki konsekuensi atas sikap patuh dan tunduk menjadi prasyarat penting yang harus dipenuhi masyarakat. Budaya yang sedemikian tentunya menciptakan adanya pergerseran moral dan etika dalam kehidupan yang selalu mengedepankan kharmonisan tanpa embel-embel pemaksaan.

Faruk (2012:153) perluasan konsep negara itu akibat adanya kepentingan kebudayaan dalam teori Gramsci. Itulah sebabnya, ia juga berbicara tentang negara "etis" atau negara "kebudayaan". Setiap negara dikatakan etis sejauh salah satu fungsi terpentingnya adalah untuk membangkitkan/mengangkat masa penduduk yang besar pada level moral dan kultural, suatu level yang berhubungan dengan kebutuhan akan kekuatan-kekuatan produktif, dengan interes-interes kelas penguasa.

Hari-hari terasa mudah dan begitu teratur, bagi Ibu. Sejak dia mengikuti kemauan komandan dan Pak Lurah, tak ada lagi orang-orang bersarung yang datang saat subuh dan menyebutnya rentenir langsung di depan hidungya. Orang-orang hanya berani berbicara di balik punggung, dan bermanis-manis di depan muka. (Madasari, 2010:87)

"Mau cari apa, Yu?" tanya salah seorang prajurit itu padaku.

"Mau ketemu si Koh, ada urusan sedikit", jawabku.

"Ada urusan apa sama Cina? Mau beli radio, hah... apa tivi?

Cari saja ke toko lain sana. Banyak juga yang jual."

"Wah, bukan mau beli barang, Ndan. Mau ada perlu."

"Ada parlu apa, hah? Sudahlah, nggak usah bakar dupa. Bisa-bisa sampeyan nanti masalah." (Madasari, 2010:107)

Hmm... apa lagi kalau bukan itu. Tentara-tentara itu, apa pun yang mereka lakukan, apa pun yang mereka katakan, intinya ya duit. Selama kita nuruti perminataan mereka, memberikan berapa pun duit yang diminta, beres urusan cari makan dan urusan dagang. Bertahun-tahun orang tidak berani lagi mengganggu urusanku yak arena tentara-tentara itu sudah kusumpal pakai duit. (Madasari, 2010:111)

Williams (Faruk, 2012:155) lebih lanjut menyatakan, bahwa hegemoni merupakan suatu proses, bukan merupakan bentuk dominasi yang secara pasif, melainkan sesuatu yang harus terus-menerus diperbaharui, diciptakan kembali, dipertahankan dan dimodifikasi. Ia menyarankan akan lebih berguna berbicara mengenai hegemoni dan dominasi untuk menarik perhatian terhadap bagaimana cara kerja hegemoni harus secara konstan diciptakan kembali dan juga terhadap bagaimana kehadiran perlawanan yang konstan, tantangan-tantangan, keteganganketegangan dan kemunculan yang mungkin dari gerakan tandingan, hegemoni atau suatu hegemoni alternatif. Dengan demikian, konsep hegemoni tidak hanya mengenai proses kultural dalam perananya yang aktif dan konstitutif, tetapi juga berurusan dengan bentuk-bentuk kultural oposisional dan alternatif yang mungkin menentang tatanan dominan, bahkan ketika bentuk-bentuk itu masih terbungkus atau termarginalisasikan oleh batas-batas dan tekanan hegemonik.

Ndak harus ikut, Yu. Kita Cuma mau minta dipinjami mobil sehari itu. Namanya buat negara, jadi ya hitunganya sumbangan. Bisa to, Yu?" 
Bisa to, bisa to, tapi harus bisa. Wong sudah tahu roda empat buat cari duit kok malah dipinjam seharian buat kampanye. Sudah meminjami kendaraan gratis, aku masih disuruh mengisi bensin. Pura-puranya tanya bisa to. Kalau aku jawab tidak bisa, nanti pasti dianggap bukan orang pemerintah. Pasti diungkit-ungkit lagi bahwa aku sudah nyekik leher wong cilik. Pasti tidak lama lagi tentara-tentara datang, minta jatah yang di luar jatah biasanya. Ya sudah, aku nggak punya pilihan lain, to? (Madasari, 2010:114)

Semua urusan selesai cepat dengan uang. Polisi-polisi itu membiarkan kami pergi membawa kendaraan kami. Orang dari bengkel menariknya dengan truk yang sudah digandeng-gandengkan dengan kawat. Pemilik bengkel itu Koh Sanjaya, teman Koh Cahyadi yang ikut dalam rombongan tirakat ke petirahan Gunung Kawi. Bengkel ini hanya salah satu Sanjaya, selain bus trayek Madiun-Ngawi. (Madasari, 2010:119-120)

Penerapan hegemoni tidak hanya untuk mendikte ideologi masyarakat, tetapi juga membiasakan masyarakat untuk berpikir dalam melayani kepentingan negara, dengan tujuan memperoleh kemudahan dalam segala aktifitas. Hal itu juga membuktikan, bahwa negara menerapkan kapitalisme. Seperti yang diungkapkan Gramsci, bahwa tujuan hegemoni tidak saja mengendalikan masyarakat, tetapi juga menciptakan tindakan-tindakan kapitalisme untuk melindungi kepentingan kelompok maupun individu.

Seperti pada kutipan tersebut, penerapan hegemoni membuat negara tidak lagi memedulikan kelas masyarakat dari segi ekonomi, masyarakat yang tergolong miskin, sedang, atau kaya mendapat perlakuan yang sama. Oleh sebab itu, pada data tersebut juga tergambar secara jelas, bahwa setiap invidu yang memiliki kekuatan ekonomi, akan lebih mudah mendapat pelayanan dari negara, yang sangat berbeda dengan golongan masyarakat bawah, selalu mendapatkan diskriminasi.

BRAK! Polisi itu menggebrak meja. Semua orang di ruangan itu terkejut, termasuk aku. Apakah omonganku keterlaluan? Tapi bukankanh aku benar? Aku tidak tahu apa-apa, aku meminjamkan kendaraan tanpa dapat uang untuk urusan kampanye, roda empatku remuk, sekarang malah aku yang diperas.

"Sampeyan jangan sembarangan kalau ngomong! Siapa yang meresmeres? Ini memang atuaranya seperti itu. Mau kalian masuk penjara?"(Madasari, 2010:118)

Masyarakat yang tidak mau patuh dan tunduk terhadap perintah negara, menjadi objek dalam tindakan kekerasan yang dilakukan oleh negara. Data tersebut menunjukkan adanya praktik intimidasi yang dilakukan oleh negara dalam penyelenggaraan pemilu. Sebelum pemilu dilaksanakan masyarakat disuguhi hiburan, sebagai bagian dari wacana keberhasilan negara dalam menyelenggarakan pemerintahan, serta wujud sikap negara dalam mengayomi dalam merangkul semua golongan masyarakat. Namun demikian, terdapat pesan politik yang tentunya harus dibayar oleh masyarakat untuk memilih partai pemerintah dalam penyelenggaraan pemilu. 
"Wah Kok mahal sekali Pak? Belum nanti saya harus membayar uang bengkel," jawabku cepat sebelum Teja mendahuluinya.

"Ini bukan saya yang bikin mahal, Bu. Ini aturan negara. Saya bukan bakul yang bisa ditawar-tawar." (Madasari, 2010:119)

Aparat memiliki tugas dan fungsi dalam menciptakan dan menjaga keamanan, serta ketertiban masyarakat. Namun pada kutipan tersebut justru melakukan tindak kekerasan serta kesewang-wenangan terhadap masyarakat. Aparat tersebut hanya mau menjalankan tugas dan fungsinya ketika masyarakat juga membayar kewajiban (memberi uang) kepada mereka. Dapat dipahami bahwa, aparat sebagai alat pemerintahan memiliki kekuatan untuk medominasi, terhadap segala kegiatan yang mengatasnamakan negara.

Dominasi negara terhadap masyarakat melalui aparaturnya menjadi modal penting, dalam menciptakan hegemoni serta menerapkan hegemoni dalam masyarakat, dengan tujuan: pertama $a_{s}$ menciptakan rasa takut kepada masyarakat, dengan demikian tujuan kedua, negara memiliki keleluasaan dalam menerapkan "peraturanya", seperti pada kutipan berikut.

"Ndak usah ikut, Yu. Kita Cuma mau minta dipinjami mobil sehari itu. Namanya buat negara, jadi ya hitungan sumbangan. Bisa to, Yu?"

"Bisa to, bisa to, tapi harus bisa. Wong sudah tahu roda empat buat cari duit kok malah dipinjam seharian buat kampanye. Sudah meminjami kendaraan gratis, aku masih disuuruh mengisi bensin. Pura-puranya tanya bisato, bisa to."(Madasari, 2010:63)

Data tersebut menujukkan bahwa, dalam konteks kehidupan masyarakat sipil, negara sebenarnya memberikan ruang kepada masyarakat dalam menjalankan setiap aktivitas, guna memenuhi kebutuhan hidup. Namun demikian, dalam konteks politik, negara memberikan tekanan kepada masyarakat dalam upaya mengendalikan, melalui berbagai tindak kekerasan. Sejalan dengan pendapat Gramsci (Faruk (2012:152-153) bahwa dalam praktik hegemoni terdapat dua ruang yang dapat digunakan, pertama masyarakat umum (sipil), kedua masyarakat dalam ranah politik. Pada ruang pertama penting dalam menanamkan ideologi hegemoni, karena pada ruang tersebut merupakan wilayah "persetujuan" dan "kebebasan kehendak", sedangkan pada wilayah kedua lebih pada iemplementasi dunia kekerasan, pemaksaan, dan intervensi.

Semua urusan cepat selesai dengan uang. Polisi-polisi itu membiarkan kami pergi membawa kendaraan kami. Orang dari bengkel menariknya dengan truk yang sudah digandengkan dengan kawat. Pemilik bengkel itu Koh Sanjaya, teman Koh Cahyadi yang ikut dalam rombongan ke petirahan Gunung Kawi, bengkel ini hanya salah satu usaha Sanjaya, selain Bus trayek Madiun-Ngawi (Madasari, 2010:120).

Kutipan tersebut menunjukkan bahwa, praktik hegemoni yang dilakukan negara merupakan upaya aktif dalam mendominasi masyarakat sipil. Agar mereka mau menuruti semua kepentingan negara, tanpa memedulikan akibat yang ditimbulkan. Faruk (2012:153) negara berhak melakukan segala aktivitas secara teoretis dan praktis, yang mana kelas penguasa (negara) tidak hanya dapat mempertahankan dominasinya, melainkan juga berupaya untuk mendapatkan persetujuan atas segala yang dilakukan.

Lagi-lagi pemilu dimenangkan partai pemerintah. Ya memang sudah semestinya to, wong semua harus nyoblos itu. Seperti sebelumnya, dibuat 
pesta syukuran semalam suntuk. Bedanya kalua dulu hanya gambyong, sekarang ditambah wayang kulit. Kalau mikir hiburan seperti ini, ya pantas orang-orang pada nunggu pemilu. Soalnya, kalua tidak ada pemilu, kapan lagi Singget ada pertunjukan wayang kulit (Madasari, 2010:122)

Penerapan hegemoni sebagai suatu ideologi tidak saja mengakibatkan luka secara fisik, namun juga menimbulkan trauma tersendiri bagi masyarakat. Penerapan hegemoni sebagai ideologi, menciptakan adanya kelas-kelas sosial, yang dalam hal ini, dapat menimbulkan konflik horizontal antar kelompok dengan kelompok atau kelompok dengan invidu, serta dengan tangan-tangan negara.

Masyarakat yang terdominasi tidak dapat berbuat banyak, sebab mereka tidak memiliki kermampuan dan kekuatan dalam melakukan perlawanan. Negara sebagai pengayom, penegak keadilan, pemberi kehidupan tidak hadir, ketika mereka memiliki kepentingan politik, untuk menjaga eksistensinya dalam pemeritahan.

Matahari belum terbit, waktu tiba-tiba kudengar teriakan dari arah belakang rumah. Itu rumah Tikno, yang sekarang hanya ditempati anak dan istrinya. Sebelas tahun lalu, Tikno dipenjara karena tidak mau menyerahkan tanahnya yang hanya sepetak itu kepada negara. Ya siapa yang mau menyerahkan kalau itu tanah warisan leluhur yang keramat. Tapi, ya siapa yang bisa menentang negara. Tantara-tentara itu menyebutnya golongan PKI. Tikno masuk penjara dan tak pernah Kembali sampai sekarang (Madasari, 2010:128)

Faruk (2012:148) menurut Gramcsi, untuk melawan praktik hegemoni manusia memerlukan kesadaran untuk dapat berpikir kritis tentang dirinya sendiri, yang dapat membangkitkan kesadaran untuk dapat melawan hegemoni, sehingga dapat terdapat upaya yang dapat dilakukan dengan kesadara diri yang progresif, yang terdapat teori dan praktik di dalamnya.

Masyarakat yang menjadi korban dalam praktik hegemoni, sebenarnya memiliki kesadaran, bahwa mereka hanya dimanfaatkan, diperalat, diperbudak oleh penguasa, hanya saja kesadaran itu gagasan semata tanpa bisa berbuat banyak. Semua usaha perlawanan yang dilakukan hanya akan berujung pada kekerasan, arogansi, serta penyiksaan yang merupakan wujud dari peradilan sesat.

"Partai beringin menang. Hanya ada dua orang yang nyoblos partai lain.

Orang-orang bilang itu pasti Mbah Sholeh imam di masjid. Dia pasti yang nyoblos Partai Islam. Satunya diperkirakan pasti Pak Ratmadi, kepala sekolahku orang-orang dia abangan. Di rumahnya ada gambar soekarno besar yang sedang menunjuk. Dulu, gambar itu dipasang di dinding luar rumah. Lalu tentara datang meminta gambar itu dicopot. Pak Ratmadi menuruti, dan memindahkan gambar itu ke dinding kamarnya. (Madasari, 2010:66)

Data tersebut menunjukkan masyarakat terintimidasi untuk memenangkan partai penguasa, praktik tersebut tidak hanya dilakukan dalam mewujudkan aspirasi dalam berdemokrasi, namun juga dilakukan dalam kehidupan sehari-hari, bahwa lukisan atau aksesoris rumah dapat menjadi penyebab terjadinya seseorang, dikucilkan dalam suatu kelompok masyarakat. Hal tersebut merupakan bukti bahwa hegemoni tidak saja memiliki dampak sesaat, tapi juga memiliki dampak secara berkepanjangan, bahkan melekat pada pemikiran-pemikiran masyarakat tentang segala sesuatu yang dihalalkan serta diharamkan oleh pemerintah. 
Ariel Heryanto (Philpott, 2003:227) kekuasaan dengan menyatakan bahwa di era Orde Baru;'kekuasaan mengejawantah dalam bentuk kekerasan dan kebrutalan yang berlebihan. Orang Indonesia tidak memerlukan filsafat atau kritik budaya, baik dari Prancis maupun negara lainya, untuk memberitahu mereka bahwa kekuasaan ada di mana-mana, atau betapa membelenggunya kekuasaan yang dimiliki oleh sekolah, kantor, maupun pabrik mereka.

Heryanto (Philpott, 2003:227) lebih lanjut menyatakan, berlangsungnya otoritarianisme di Indonesia dalam jangka lama dan penggunaan kekuatan (pemaksa) oleh pemerintahan Soeharto dan Habibie membuat keberatan-keberatan seperti itu bisa dimanfaatkan untuk mengeksplorasi pembahasan kekuasaan dari sudut lain. Pada satu sisi, Heryanto benar ketika mengobservasi bahwa kekuasaan ada di mana-mana, tetapi apa yang sebut dengan kekuasaan bisa dimengerti sebagai dominasi.

\section{Simpulan}

Berdasarkan hasil penelitian yang dilakukan, ditemukan dua bentuk hegemoni ideologi yang dilakukan oleh negara kepada masyarakat. Adapun bentuk hegemoni ideologi terwujud dalam bentuk: pertama, kekerasan secara verbal yang dilakukan oleh aparatur negara (Tentara/Polisi), kedua, kekerasan yang dilakuan dengan fisik dilakukan oleh aparut negara (Tentara/Polisi). Penerapan Hegemoni seperti pada bagian sebelumnya, merupakan wujud dari keseriusan negara dalam menjaga stabilitas kekuasaan, tanpa memedulikan masyarakat.

\section{Saran}

Berdasarkan hasil serta simpulan tersebut, terdapat beberapa aspek yang perlu disarankan penulis;

1. Pada proses pengajaran sastra novel Entrok dapat digunakan sebagai salah satu referensi media apresiasi, untuk meningkatkan wawasan mahasiswa mengenai praktik hegemoni dalam novel.

2. Pemahaman tentang teori serta hasil analisis tentang hegemoni, disarankan sebagai pijakan untuk mengembangkan teori-teori tersebut dalam menganalisis fungsi pemerintah, yang terdapat dalam semua genre karya sastra.

3. Hasil analisis penelitian kekerasan yang terepresentasikan dalam novel Entrok, masih memiliki kekurangan. Oleh sebab itu, diperlukan penelitian yang lebih mendalam.

\section{DAFTAR PUSTAKA}

Bungin, Burhan. 2006. Metode Penelitian Kualitatif. Jakarta: PT. Raja Grafindo Persada.

Faruk. 2013. Pengantar Sosiologi Sastra. Yogyakarta: Pustaka Pelajar.

Madasari, Okyy. 2010. Entrok. Jakarta. PT. Gramedia Pustaka Utama.

Philpott, Simon. 2003. Meruntuhkan Indonesia. Yogyakarta: LKiS.

Simon, Roger. 1999. Gagasan-Gagasan Politik Gramsci (penerjemah Kamdani

Sudarmayanti dan Hidayat. 2002. Metodologi Penelitian. Bandung: Mandar Maju. 